\title{
STUDENT PERCEPTION OF THE BASIC ENGINEERING LEARNING MODEL THROUGH THE PLAY APPROACH
}

\author{
Siti Ayu Risma Putri', Muhsana El Cintami Lanos², Hikmah Lestari³, \\ Mutiara Fajar ${ }^{4}$ \\ PGRI University Of Palembang ${ }^{1234}$, Indonesian \\ Sitiayurisma@gmail.com, elcintami14@gmail.com
}

\begin{abstract}
This study aims to determine students' perceptions of the volleyball basic technique learning model through a play approach based on (1) Perceptions of learning knowledge of basic volleyball techniques, (2) Perceptions of teacher teaching styles, (3) Perceptions of the media used are easy to use, (4) Perceptions about the interest in learning basic volleyball techniques, (5) Perceptions about the need to develop a volleyball basic technique learning model through a play approach were obtained. This research is a descriptive quantitative research. The results of this study indicate that (1) Perceptions of basic volleyball technique learning knowledge obtained a value of $95 \%$ in the very good category, (2) Perceptions of the teacher's teaching style obtained a value of $73.13 \%$ in the good category, (3) Perception of the media which is used easy to use obtained a value of $85 \%$ with a very good category, (4) Perceptions about the interest in learning the basic techniques of volleyball obtained a value of 95\% with a very good category, (5) Perceptions about the need to develop a volleyball basic technique learning model through the playing approach obtained the value is $100 \%$ in the very good category, which means that students agree if the development of a volleyball basic technique learning model through a playing approach is developed. The results of this study indicate that students' perceptions of the development of a volleyball basic technique learning model through a play approach in junior high schools in Palembang are positive, for that it is necessary to develop a volleyball basic technique learning model through a play approach.
\end{abstract}

Keywords: Student perceptions, basic techniques, volleyball, playing

Correspondence author: siti ayu risma putri, universitas PGRI Palembang, indonesia. E-Mail: sitiayurisma@gmail.com 


\section{INTRODUCTION}

Physical education is a learning process through physical activities designed to improve physical fitness, develop motor skills, knowledge and behavior for healthy and active living, sportsmanship, and emotional intelligence. Physical education is a learning process through physical activities designed to improve physical fitness, develop motor skills, knowledge and behavior for healthy and active living, sportsmanship, and emotional intelligence (Samsudin, 2013). The learning environment is carefully regulated to foster the growth and development of all students, physical, psychomotor, cognitive, and affective realms (Arfa et al., 2020). All activities that involve physical must be supported by good physical fitness because physical fitness is the ability of a person'sbody to carry out daily work tasks, without causing significant fatigue (Nurhasan, 2011). According to (Parker, et.al, 2018) This study explores the relationship between primary school physical education and physical activity as sites for the practice of physical activity of Irish primary school children Understanding how children make connections. which means that activities in learning complex motor skills initially become a simplified form, with the aim of making it easier to understand the movements to be performed. Making exercise a motor skill complex initially in a simplified form (Raiola,2015).

Physical education learning in schools has several materials, one of which is volleyball which is included in the big ball game material. Volleyball is a fun sport, this game is a team sport played by six people per team and this game will run well if every player has at least mastered the basic techniques of playing volleyball (Wa'asil et al., 2019). Volleyball is a sport played by two opposing teams bounded by a net (Gall et al., 2007). Volleyball is one of the truly global sports, played in sports halls and arenas (219 national federations are affiliated to the FIVB) and in parks, open spaces, and on beaches throughout the world (Waite Pete, 2009). Volleyball is a very popular sport, and its development is full of constantly innovation and maturity of techniques and tactics (Yiannis\&Panagiotis, 2005).

Volleyball is a sport that is classified as a big ball game and is in great demand by students and Indonesians, because this sport is indeed an alternative sport that is quite easy to master and can be played anywhere without expensive costs (S. Ayu , 2020). 
Volleyball sports and has several basic techniques including top serve, under serve, smash, over and under passing, in learning volleyball is a popular sport, fun so that students are very happy to do this sport. However, volleyball learning has several basic techniques that must be mastered skillfully by students so that the need for planning and strategy in learning mastery of movement skills, movement skills have stages in the process.

Passing is a technique of bouncing the ball using your hands, so that the ball can bounce off and can be given to the next player to attack the opponent's defense area. passing is a way of hitting the ball with two hands that are joined and swung from below (passing under) or hitting the ball with two separate hands with open fingers above the head slightly forward (passing over). (Barth. \&Heuchert, 2007) said that Passing or called a set is a gap where the ball is positioned for a teammate to attack. One of the skills in volleyball is passing skills. (Musthofa et al., 2016) stated that passing in volleyball is a term for how to play the first ball after the ball is in play due to an opponent's attack, opponent's service, or net play (cover spike and cover block). Another opinion is also stated (Ahmadi, 2007) that defining passing is an effort to soprang a player with a certain technique to pass the ball played to his teammate played in his own field.

In the sport of volleyball, service is also an initial attack, because of that every player who serves will try to make a service ball that kills the opponent, such as fast, hard, aiming at empty areas, aiming at weak players, not really good at passing or so. "The main serves now being used are the floater, the standing topspin, the jump floater, the jump topspin, and the hybrid a combination of the jump floater and the topspin" (Waite Pete, 2009) explains that service is what is now being used is floater, standing topspin, jumping float, jump topspin, and a hybrid, a combination of a jump floater and topspin.A service ball that is done very well and is deadly is indeed very important to do in starting a game, besides being able to turn off your opponent and get points / value directly, this service ball can make it difficult for the opponent to return the ball or arrange a perfect attack.

"The serve is important because it brings the wall into play and opens ups the move" (Barth. \&Heuchert, 2007) which explains that service is very important because a game starts with a serve before making a match. Servicing is one of the basic techniques 
by bouncing the ball upwards first then continuing to swing the arm from behind to front.

"This game begins with the server and the opponent side is then allowed to use only hands to make contact with the ball and throw the ball over the net" (Perumalsamy et al., 2014).

Blocking is one of the basic techniques of volleyball which is very important as a form of team defense, because with this blocking technique the team can stem attacks from opposing players. The definition of block itself is a form of effort made by volleyball players to stem attacks / smashes launched by opposing players. According to (Ahmadi, 2007), the block is the main defense to fend off enemy attacks. In addition, Block is defined (Reeser\& Bahr, 2008) as the block is a defensive movement performed in reaction to the opponent's attack, explaining that a block is a defensive movement that is carried out in reaction to an opponent's attack. According to (Muhajir, 2004), Block (Dam) is very close to the defensive technique that is carried out over the net, Block's success can be determined by the high jump and the ability to reach the arm on the ball that is being hit by the opponent. Blocks can be done by one, two, or three players depending on the quality of the opposing players, and blocks can be done actively and passively.

In the sport of volleyball, one of the basic techniques known is block. This technique appears when the opponent smashes and the defending player jumps in front of the net and blocks his hand to block the ball from the opponent's attack. The dam is the first defense from the opponent's attack. Basically a block is a technique by blocking or blocking the enemy while carrying out an attack in front of the net by lifting the arm high above the net, where he thinks is the direction of the ball.

In the development of volleyball, blocking is a minor skill. Blocking is the most difficult volleyball skill to teach and to learn (Edwards, 2011) explains that Blocking is the most difficult volleyball skill to teach and learn. According to (Iskandar, 2013) Block I dam is one of the basic techniques of volleyball that emphasizes defense by jumping near the net by reaching out as high as possible in an effort to stem the opponent's attacks. This technique has complex movements compared to other basic volleyball techniques. Block is the most important skill in the early game levels. When ball control is 
inconsistent, the potential for a strong attack is uncertain Smash is a technique performed by volleyball players whose aim is to attack the opponent's area, so that the ball that will be crossed to the opponent's area can be deadly at least making it difficult for the opponent to play the ball perfectly. Smash (spike) is the most interesting part or the location of the art in a volleyball game. It is also the most difficult technique to learn of all the techniques involved in volleyball. A speaker must have agility, be able to jump high, have good feeling, and have the ability to hit the ball as hard and smart as possible. To make a smash a smasher must jump into the air then sharply and carefully strike the ball moving over the net so that it lands on the opponent's court.

(Palao et al., 2009) states that "Attack is standard technique (standard jump and arm swing) and other techniques (variations or modifications of the standard technique, either in the jump or in the arm swing)" explains that the attack is a standard technique. (standard jump and swing arm) and other techniques (variations or modifications to standard techniques, either in the jump or in the arm. Another opinion says (Kristriawan\&Sukadiyanto, 2016) Smash is hitting the ball towards the opponent so that the ball can cross the net and cannot be returned by opponents and the hitting team get points.Smash or commonly known as attack is a form of playing a game that plays a very important role in playing volleyball, because this technique is the most effective way to turn off the opponent's defense or kill the ball in the opponent's field and at the same time to get points.

Therefore, the smash technique really needs to be mastered by a volleyball player, because teams that have a good smash have a great chance of winning the game in a match. According to (M. Yunus, 1992) that the smash is the main blow in the attack in achieving victory. The goal in volleyball is to hit the right hard shots and score at every opportunity, as it is a condition for the team to be declared the winner. The success of a team in the game is always determined by their success in smashing. (Beutelstahl, 2001) also said that someone who is good at smash "smasher" must have agility, be good at jumping, and have the ability to hit the ball as hard as possible.

Explain that this game starts with the server and the opposing side is then only allowed to use the hand to make contact with the ball and throw the ball over the net. There are several kinds of basic volleyball techniques, one of which is serve.(Beutelsthal, 
2005) states that service can aim to immediately score a victory and hinder the formation of the opponent's attack. Volleyball games must master basic service techniques well so that the success rate of service is high. According to (Bonny Jill Ferguson, \& Barbara L, 2000) "that in a match, it is very important for players to provide consistent service, that is, at least $90 \%$ of the player's service can pass the net to the opponent's area". Another opinion suggests that serve is a ball hit from behind the finish line of the playing court over the net to the opponent's playing area

This is reinforced by the opinion which states that Childhood and adolescence are essential periods for learning, mainly due to the rapid neurodevelopment and greater neural plasticity, that is, experience in this period alters the architecture (Silva, et.al,2017).Volleyball learning in school has been going quite well, but several obstacles were found during the learning process including students having a lot of difficulty in doing the basic volleyball techniques correctly, the lack of variations in learning the basic volley ball techniques applied.

Theneedforrenewal in volleyball learning in junior high school. Student learning readiness is largely determined by the teacher's learning design. Apart from being wellorganized and systematic, the design must also be varied. In this case, the vocabulary of variations in learning activities owned by the teacher is very important to present interesting and appropriate learning. Given the importance of adjusting physical education learning, especially volleyball learning with student characteristics, learning equipment, learning resources and game-centered methods, researchers took the initiative to develop a volleyball learning model for junior high schools. The application of a gamecentered approach in physical education classes has the potential to improve student learning and develop students as active learners (Nieves et al., 2019).

Volleyball is a fun sport that can be played anywhere with any number of players, players can give great individual performances but but these players are part of the team. Based on this, this sport is very suitable when applied in school because, in sports volleyball contains elements that are in accordance with the objectives of learning physical education at school. Volleyball provides an opportunity for both boys and girls to participate in games that avoid direct body contact but still provide some interesting play. It is a game that calls for individual excellence in learning to play and provides real 
opportunities for sportsmanship. The game presents dramatic, spectacular and thrilling situations for both the player and the audience. It has everything a sport needs

Tracing literature studies on research (Hutagalung et al., 2020). Developing volleyball learning written in his research under the title Development of Volleyball Service Learning Model for Seventh Grade Students. This study developed a volleyball service learning model based on two criteria, namely: (1) instructional criteria and (2) representation criteria (presentation criteria). In this study, the researcher made a volleyball basic technique learning model through a play approach, by creating a learning model through a play approach so that students were expected to learn with items of variations in the volleyball learning model covering all basic volleyball techniques, which were based on the characteristics of the beginner, the means and suitable infrastructure, and attractive methods. Activities that are developed use game-centered principles, so they become more interesting and fun.

Based on the foregoing, to determine students' perceptions of the product to be developed by researchers, it is necessary to distribute questionnaires in the form of questionnaires to students in three junior high schools in Palembang, namely SMPN 29, SMPN 42. The need for student perceptions of research products to be developed for furthermore, so that the research results obtained are feasible to apply

\section{METOD}

This research is a descriptive quantitative research. This research was conducted at SMPN 29 and SMPN 42 Palembang city. The research subjects were 40 students. The research used in the form of a questionnaire contains a number of questions that must be answered by respondents (Maksum, 2008). The results of the research data are (1) Perceptions of the basic volleyball technique learning knowledge, (2) Perceptions of the teacher's teaching style, (3) Perceptions of the easy-to-use media used, (4) Perceptions of interest in learning basic volleyball techniques, (5) Perception of the need to develop a volleyball basic technique learning model through a play approach is obtained.

The results of the data from the questionnaires that were filled in were then presented with (Sugiyono, 2008) the formula used to process the data as follows:

$$
\mathrm{P}=\frac{x}{x i} x 100 \%
$$


Information:

$\mathrm{P} \quad$ : Percentage of evaluation results on trial subjects.

$\mathrm{X} \quad$ : The number of score answers by the testsubject.

$\mathrm{Xi} \quad$ : The maximum number of answers in the assessment by the test subject.

$100 \%$ : Constant

To facilitate conclusions on the results of the analysis of the percentage level of attractiveness and convenience of product development, classification criteria are set.

Table 1. Category

\begin{tabular}{cll}
\hline Percentage & Category & Information \\
\hline $80-100 \%$ & Very good & Can be used without revision \\
\hline $61-80 \%$ & Good & Can be used with minor revisions \\
\hline $41-60 \%$ & Pretty good & $\begin{array}{l}\text { Not suitable for use, it is recommended not to } \\
\text { use it }\end{array}$ \\
\hline $21-40 \%$ & Not good & Can not be used \\
\hline
\end{tabular}

\section{RESULT AND DISCUSSION}

The data analysis of the research results was obtained based on a questionnaire distributed to students with four indicators using the Guttman scale with the results of the calculation of the frequency of answers, the average score, namely (1) Perceptions of the knowledge of learning basic volleyball techniques obtained by a value of $95 \%$ with very good category, (2) Perceptions of the teacher's teaching style obtained a value of $73.13 \%$ with good categories, (3) Perceptions of the media used are easy to use, obtained a value of $85 \%$ with a very good category, (4) Perceptions of interest in learning basic techniques of volleyball are $95 \%$ with very good category, (5) Perceptions of the need to develop a volleyball basic technique learning model through a play approach obtained a value of $100 \%$ with a very good category, which means that students agree if the development of a volleyball basic technique learning model through the playing approach 


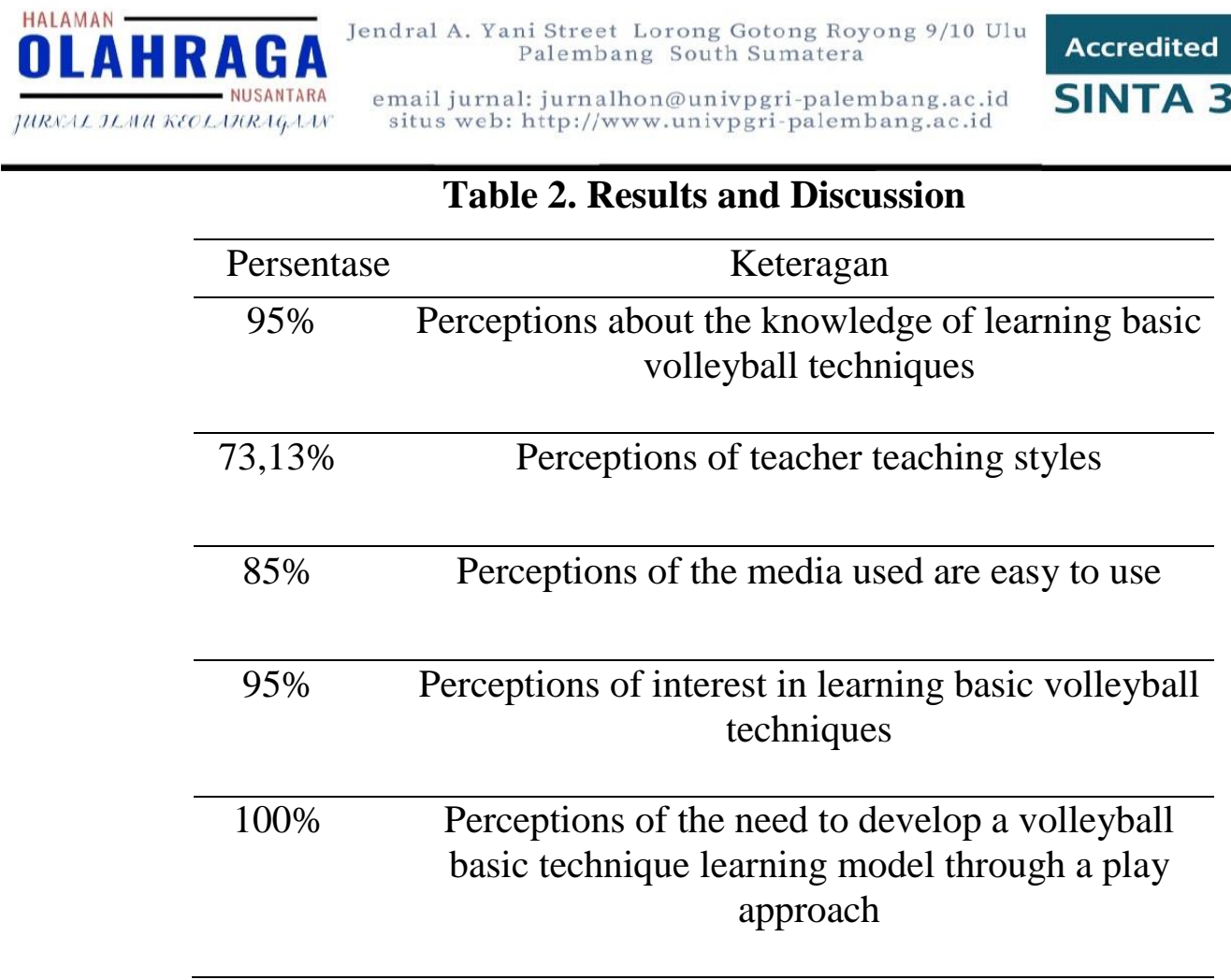

Based on the foregoing, it can be concluded that students' perceptions of the development of a volleyball basic technique learning model through the playing approach of junior high school students in Palembang are positive. The learning approach through play will help students transfer knowledge to be provided by the teacher more fun. The approach to the learning process of basic volleyball techniques must be able to make the child happy and feel that it is not difficult to do this volleyball sport. This can increase interest and enthusiasm in learning so that students can do basic volleyball techniques correctly and achieve their learning objectives.

\section{CONCLUSION}

Students' perceptions of the volleyball basic technique learning model through the play approach that they want to develop are positive and more meaningful. This shows that students understand the main concepts and needs inlearning through a play approach that involves students in active and fun learning. Based on this, the volleyball basic technique learning model through the play approach can answer obstacles about the difficulties of students in learning basic volleyball techniques in the learning process. Volleyball basic technique learning model through the play approach can be useful for teachers, volleyball coaches, students and the community in general as reference material in learning basic volleyball techniques. 


\section{THANK YOU}

We are very grateful to the Chancellor of the PGRI Palembang University, the Dean of the Teacher Training and Education Faculty (FKIP) PGRI Palembang University for the Physical Education study program, and all those who have contributed to the writing of this article. Hopefully this journal can be useful for everyone.

\section{REFERENCE}

Afandi M., EviChamalah, Oktarina P. (2013). Model dan pembelajaran disekolah.

Arfa, M., Akhmad, I., \&Nugraha, T. (2020). Different Effects Between Cooperative and Sociometric Learning on Lower Passing Learning Outcomes in Volleyball Games of Grade VIII Students at SMP Negeri 14 Medan. 384(Aisteel), 475478.https://doi.org/10.2991/aisteel-19.2019.105

Gall, M. D., Gall,J. P., \& Borg, W. R. (2007). Educational Research, An Introduction (Eighth Edt). Pearson Education, Inc.

Hutagalung, E. A., Sunarno, A., \&Hasibuan, S. (2020). Development ofVolleyball Service Learning Model for Seventh Grade Students. 1st Unimed International Conference on Sport Science (UnICoSS 2019), 23(UnICoSS 2019), 187-189.

Lee Sunhee, Yeung Chung. (2018). When Technology, Science and Culture Meet: Insights from Ancient Chinese Technology. V13 n2 p485-515, eric.ed.gov/EJ1182443

Maskun,A.2008.Metodelogi Penelitian dalam Olahraga .Surabaya :Universitas Negeri Surabaya.

Nieves, A. M., Oliver, L. E., \& Oliver, L. E. (2019).Introducing a TGfU Mini- volleyball Unit. Journal of Physical Education, Recreation \&Dance ISSN:, 90(9), 5660.https://doi.org/10.1080/07303084.2019.1658499

Nurhasan. (2011). Tips Praktis Menjaga Kebugaran Jasmani. Abil Pustaka.

Parker,Melissa,et.al.(2019).'Drawing'Conclusions:Irish Primary School Children's Understanding of Physical Education and Physical Activity Opportunities outside of School. v24 n4 p449-466 Nov 2018, eric.ed.gov/ EJ1192692/

Raiola\& Gaetano, et.al. (2015). Teaching method of physical education and sports by prescriptive or heuristic learning. vol. 10, núm.1, 2015,pp. S377-S384. Journal of Human Sport and Exercise

Samsudin.(2013). PembelajaranPedidikanJasmaniOlahragadanKesehatan SMP/MTs. UNJ.Semarang :Unissula Press

Silva, A. Z., Pereira, F. L., Mincewicz, G., \&Arauj, L. B. (2017). Psychomotor Intervention To Stimulate Motor Development In 8-10-Year-Old Schoolchildren. RevistaBrasileira de Cineantropometria e DesempenhoHumano, 19(2). 


\section{DLAHRAGA}

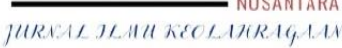

Jendral A. Yani Street Lorong Gotong Royong 9/10 Ulu Palembang South Sumatera

\section{Accredited}

email jurnal: jurnalhon@univpgri-palembang.ac.id situs web: http://www.univpgri-palembang.ac.id

S. Ayu, R. Putri, and P. Education, "Kinestetik: Jurnal Ilmiah Pendidikan Jasmani Personality Of Volleyball Athletes Faculty Student Activity Unit (UKMF)," vol. 4, no. 2, 2020.

Wa'asil, F., Hernawan, H., \&Humaid, H. (2019).Defense Exercise Model of Volleyball Fw for Beginner.JurnalPendidikanOlahraga, 7(2), https://doi.org/10.31571/jpo.v7i2.116696.

Waite Pete. (2009). Aggressive Volleyball.Human Kinetics.

Yiannis, L., \&Panagiotis, K. (2005). Evolution in men's volleyball skills and tactics as evidenced in the Athens 2004 Olympic Games. International Journal of Performance Analysis in Sport, 5(2), 1-8. https://doi.org/10.1080/24748668.2005.11868 
Siti Ayu Risma Putri, Muhsana El Cintami Lanos, Hikmah Lestari, Mutiara Fajar (2021) Student Perception of the Basic Engineering Learning Model Through The Play Approach

\section{OLA ARAGA}

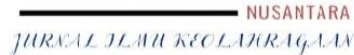

Jendral A. Yani Street Lorong Gotong Royong 9/10 Ulu Palembang South Sumatera

email jurnal: jurnalhon@univpgri-palembang.ac.id situs web: http://www.univpgri-palembang.ac.id
Accredited

SINTA 3 